Rafał Mazur (1)

Uniwersytet Jagielloński, Kraków

r.mazur@uj.edu.pl

\title{
TELEWIZYJNE ORĘDZIE DO NARODU JAKO NARZĘDZIE KOMUNIKACJI KRYZYSOWEJ
}

Słowa klucze: dyskurs, komunikacja, perswazja, zarządzanie kryzysowe

Keywords: discourse, communication, persuasion, crisis management

Kryzys wywołany pandemią koronawirusa niesie ze sobą implikacje nie tylko natury zdrowotnej, ale też gospodarczej i politycznej. Instytucje państwa nie mogą być jednak zajęte wyłącznie kontrolowaniem liczby zakażonych, stabilizacją sytuacji ekonomicznej i budowaniem kompromisu politycznego. Muszą bowiem pamiętać o tym, że z punktu widzenia kapitału politycznego równie ważny co działania podejmowane w obliczu kryzysu jest sposób komunikowania społeczeństwu tych działań. Jak zauważa Dariusz Tworzydło:

[b]łędnie prowadzony proces zarządzania sytuacją kryzysową może przyczynić się [...] do nieodwracalnych zmian w zakresie wizerunku lub wręcz do jego bankructwa [...] (2012: 149).

Aby zapobiec zaistnieniu takiej sytuacji, rządzący od chwili ogłoszenia stanu pandemii sięgają po różnorodne narzędzia komunikacji politycznej. Premier wraz z ministrem zdrowia regularnie odbywają konferencje prasowe; za pośrednictwem telewizji i Internetu rozpowszechniane są kampanie społeczne promujące odpowiedzialne zachowanie; reprezentanci senackiej i sejmowej większości są stałymi gośćmi mediów, a na profilach Ministerstwa Zdrowia i Głównego Inspektoratu Sanitarnego na Twitterze odnaleźć można zarówno zalecenia dotyczące postępowania 
w trakcie pandemii, jak i aktualne statystyki zakażeń. Wszystkie te metody komunikacji cechuje jednak wada związana $\mathrm{z}$ ich ograniczonym zasięgiem. Wydaje się, że jeśli przyjąć kryterium liczby odbiorców, niezwykle skutecznym narzędziem zarządzania sytuacją kryzysową są emitowane w telewizji orędzia skierowane do narodu. Tego rodzaju wystąpienia zazwyczaj cieszą się dużym zainteresowaniem społecznym ze względu na swój uroczysty charakter (orędzie wygłaszane jest tylko w wyjątkowej sytuacji, takiej jak święto narodowe, pamiątka wydarzenia historycznego, kryzys), ale też dlatego, że są one transmitowane w telewizji w czasie najwyższej oglądalności. Z prerogatywy uprawniającej do wygłoszenia telewizyjnego orędzia służącego przedstawieniu polityki państwa w czasie pandemii jak dotychczas zdecydowały się skorzystać trzy najważniejsze osoby w państwie: prezydent Rzeczypospolitej Polskiej Andrzej Duda (dwukrotnie - 10 i 20 III 2020 r.), marszałek Sejmu IX kadencji Elżbieta Witek (31 III 2020 r.) i marszałek Senatu X kadencji Tomasz Grodzki (24 IV 2020 r.). Celem artykułu jest analiza retoryczno-argumentacyjnej warstwy tych wystąpień i zawartych w niej najważniejszych językowych strategii perswazyjnych wykorzystywanych do zarządzania kryzysem wizerunkowym.

Orędzie adresowane do narodu należy uznać za autonomiczny gatunek wypowiedzi politycznej, który charakteryzuje konwencjonalizacja i rytualność. Tego rodzaju przemówienia od innych wystąpień różnią ramowe warunki, w jakich powstaje tekst (zawczasu przygotowany scenariusz, sceneria i scenografia). Przemawiający zazwyczaj występują przed rozpoznawalnymi budynkami albo w zaciszu urzędowych gabinetów, co podkreśla oficjalny charakter odezwy. Do ważnych elementów orędzia trzeba zaliczyć budowanie poczucia więzi i bliskości między politykiem a adresatami m.in. przez bezpośrednie zwroty do współobywateli (Drodzy Rodacy / Szanowni Państwo), emocjonalność przekazu, a także podkreślanie wspólnoty wartości, świata i języka (por. Patocka-Sigłowy 2011; Czachur 2016; Noińska 2017, 2018).

Warto zauważyć, że prawo zwrócenia się do narodu w formie orędzia wynika przede wszystkim z tradycji ustrojowej, a nie z ustabilizowanej normy prawnej. Choć Konstytucja Rzeczypospolitej Polskiej wśród prerogatyw prezydenta wymienia możliwość wygłoszenia orędzia, to zgodnie z treścią art. 140 jego adresatem może być wyłącznie Sejm, Senat lub Zgromadzenie Narodowe (por. Dz.U. 1997, nr 78, poz. 483). Konstytucja nie przyznaje natomiast prezydentowi kompetencji do wygłaszania orędzi adresowanych do narodu. Mimo to prezydenci na mocy zwyczaju konstytucyjnego chętnie komunikują się bezpośrednio z obywatelami z pominięciem parlamentu (por. Banaszak 2009: 682; Kuczma 2015: 193). Nadawcą orędzia może być jednak nie tylko prezydent, ale również marszałek sejmu, marszałek senatu oraz premier. Uprawnienie do komunikowania i wyjaśniania polityki państwa za pośrednictwem publicznych kanałów radiowych i telewizyjnych gwarantuje im (w tym także prezydentowi) art. 22 ust. 2 Ustawy z 19 grudnia 1992 roku o radiofonii i telewizji (Dz.U. 2019, poz. 361). Kompetencję tę prezydentowi i marszałkom zapewnia także Rozporządzenie Krajowej Rady Radiofonii i Telewizji z 21 sierpnia 1996 roku 
w sprawie trybu postępowania w związku z prezentowaniem i wyjaśnianiem w publicznej radiofonii i telewizji polityki państwa przez naczelne organy państwowe (Dz.U. 1996, nr 109, poz. 526). Mimo że wspomniane akty prawne nie nazywają tego rodzaju wystąpień orędziami, to zwyczajowo przyjęło się je jako orędzia traktować, gdyż nie odbiegają od przemówień prezydenta w zakresie formy oraz poruszanych tematów.

Na marginesie trzeba dodać, że w kampanii wyborczej w 2020 r. także niektórzy kandydaci na urząd prezydenta zdecydowali się na publikację w przestrzeni internetowej politycznych przemówień utrzymanych w konwencji orędzia (m.in. Małgorzata Kidawa-Błońska i Szymon Hołownia). Orędzie jest bowiem skonwencjonalizowanym i łatwo rozpoznawanym gatunkiem, który przez odbiorców łączony jest przede wszystkim z prerogatywami prezydenta. Kandydaci, wygłaszając tego rodzaju odezwy, pokazywali tym samym swoim wyborcom, iż są gotowi do objęcia urzędu prezydenta i wypełniania związanych z nim obowiązków.

Można założyć, że o ile wystąpienia okolicznościowe mają funkcję integracyjną - spajają narodową zbiorowość wokół wspólnych wartości i ideałów (por. Patocka-Sigłowy 2011: 96; Noińska 2017: 398, 2018: 96), to orędzia na czas kryzysu będą podporządkowane zwłaszcza funkcji perswazyjno-informacyjnej. Zazwyczaj służą one trzem głównym celom. Po pierwsze nadawca zarysowuje sytuację, w której znajduje się państwo, i podkreśla jej powagę. Po drugie mówca postuluje konieczność podjęcia działań zapobiegających kryzysowi. Po trzecie przedstawia sposób na zażegnanie kryzysu, przekonując odbiorców co do jego słuszności i skuteczności. Realizacja takiego planu komunikacyjnego służy przedstawieniu nadawcy jako osoby mającej kompetencje do zarządzania sytuacją kryzysową, a więc wiarygodnej i godnej zaufania. Od siły przekonywania wysuwanych przez nadawcę argumentów zależy to, czy kryzys zaszkodzi jego wizerunkowi, czy też wręcz przeciwnie - pomoże w podniesieniu notowań danego polityka. Wydaje się, że do podobnych celów dążyli również ci politycy, którzy skierowali swoje słowa do narodu w czasie kryzysu wywołanego pandemią koronawirusa w pierwszej połowie $2020 \mathrm{r}$. Analizowane teksty orędzi różnią się jednak w zakresie przyjmowanych przez mówców strategii perswazyjnych. Wynika to z dwóch powodów. Przede wszystkim, mimo że publikację wystąpień oddziela jedynie około półtora miesiąca, to wypowiedzi te były przygotowywane w różnych etapach dynamicznie rozwijającej się epidemii, której towarzyszyły gwałtowne zmiany sytuacji politycznej. Drugim powodem różnic w retorycznej warstwie analizowanych tekstów jest rozbieżność, a w niektórych przypadkach nawet konflikt, interesów politycznych ich nadawców. Trzeba zauważyć, że prezydent, wygłaszając swoje orędzia, występował w roli nie tylko głowy państwa, ale też kandydata ubiegającego się o reelekcję. Marszałek sejmu i marszałek senatu przynależą natomiast do dwóch przeciwnych obozów politycznych. Można zatem założyć, że intencją ich wypowiedzi jest nie tylko budowa pozytywnego wizerunku reprezentowanych przez nich instytucji, ale też atak na politycznych przeciwników. 
Elementem powtarzającym się we wszystkich analizowanych orędziach jest podkreślenie powagi zagrożenia związanego z pandemią. Służy to przedstawieniu mówiącego jako osoby kompetentnej i odpowiedzialnej, która nie lekceważy ani nadchodzącego, ani obecnego niebezpieczeństwa, jest gotowa do podjęcia niezbędnych i zdecydowanych działań w obliczu kryzysu. Wykorzystuje się tu przede wszystkim metaforykę militarną, częstą w dyskursie politycznym. Nadawcy mówią m.in. o: walce z epidemia / mobilizacji / narzędziach i metodach walki / niewidzialnym wrogu / froncie walki z epidemia; por.:

(1) Przed nami decydujący czas. Zdaniem specjalistów zbliżamy się do kluczowego, przełomowego momentu $\mathbf{w}$ walce $\mathbf{z}$ epidemią ${ }^{1}$. Dlatego apeluję do wszystkich o jeszcze większą mobilizację, jeszcze większą dyscyplinę. Zostańmy w domach! (Duda 202ob)

(2) To dla nas wszystkich bardzo trudny czas. Mierzymy się z niewidzialnym wrogiem. Przez te ostatnie tygodnie codziennie zdajemy test $\mathrm{z}$ odpowiedzialności i wytrwałości. Ze wspólnego trwania w determinacji, by pokonać tę epidemię. Już dziś możemy powiedzieć, że narzędzia i metody do walki wybraliśmy właściwe. Mimo tego, z czym przyszło nam walczyć, jest w tych niełatwych dniach coś, co daje ogromną siłę i nadzieję na przyszłość (Witek 2020).

(3) Hotele udostępniają miejsca dla pracowników ochrony zdrowia, którzy narażają swoje zdrowie i życie na pierwszej linii frontu walki z epidemią i bojąc się o swoich najbliższych, nie wracają przez wiele dni do własnych domów (Grodzki 2020).

Obrazowanie polegające na zrównaniu metod przeciwdziałania pandemii z walką toczoną na wojennym froncie czyni użytek z retoryki oblężonej twierdzy. Wzbudzenie wśród odbiorców poczucia silnego i nieuchronnego zagrożenia wywołać ma skupienie się społeczeństwa wokół tych polityków, którzy oferują zapewnienie bezpieczeństwa. Retorykę tę wspierają również formy stopnia wyższego, którymi posługuje się prezydent, apelując o jeszcze większa mobilizację, jeszcze większa dyscyplinę. Podkreśla w ten sposób, że niebezpieczeństwo związane z rozwojem pandemii wciąż nie zostało zażegnane. Poczucie strachu budowane jest też przez takie określenia jak niewidzialny wróg - niewidzialny, więc taki, wobec którego należy zachować stałą czujność.

Dla podkreślenia zagrożenia związanego z kryzysem niebagatelne znaczenie mają również określenia temporalne. Prezydent w swoich wystąpieniach mówi o trudnych chwilach / decydującym czasie / kluczowym, przełomowym momencie $w$ walce z epidemia / trudnych dla nas wszystkich dniach. Marszałek sejmu zwraca

Wszystkie podkreślenia są odautorskie. 
zaś uwagę na to, że jest to dla nas wszystkich bardzo trudny czas. Przemawiający presuponują, iż nadzwyczajna sytuacja wymaga równie nadzwyczajnych rozwiązań. Jednocześnie solidaryzują się z odbiorcami, wyrażając zrozumienie wobec niezadowolenia wywołanego nakładanymi przez rząd ograniczeniami. Wrażenie wspólnoty między nadawcą a odbiorcami wzmacniać ma także wykorzystanie form zaimków i czasowników w 1 os. l. mn. (nas/potrafimy); por.:

(4) Zawsze w trudnych chwilach potrafimy się jednoczyć. Wzajemnie sobie pomagać. Pokazaliśmy to wielokrotnie (Duda 2020a).

(5) Przed nami decydujący czas. Zdaniem specjalistów zbliżamy się do kluczowego, przełomowego momentu w walce $\mathrm{z}$ epidemią (Duda 2020b).

(6) W tych trudnych dla nas wszystkich dniach z całego serca dziękuję służbom sanitarnym, medycznym i mundurowym (ibid.).

(7) To dla nas wszystkich bardzo trudny czas. Mierzymy się z niewidzialnym wrogiem. Przez te ostatnie tygodnie codziennie zdajemy test $\mathrm{z}$ odpowiedzialności i wytrwałości. Ze wspólnego trwania w determinacji, by pokonać tę epidemię. Już dziś możemy powiedzieć, że narzędzia i metody do walki wybraliśmy właściwe (Witek 2020).

W inny sposób okres pandemii opisuje marszałek senatu. W swoim przemówieniu korzysta on z określeń o większym ładunku emocjonalnym, takich jak czasy zarazy / straszny czas / czas cierpienia; por.:

(8) Nasz wielki Rodak, Jan Paweł II, mówił: „Ojczyzna jest naszą matką ziemską. Polska jest matką szczególną. Niełatwe są jej dzieje, zwłaszcza na przestrzeni ostatnich stuleci. Jest matką, która wiele przecierpiała i wciąż na nowo cierpi”. Dzisiaj mamy w naszej ojczyźnie po raz kolejny czas takiego cierpienia (Grodzki 2020).

(9) W imieniu Senatu Rzeczypospolitej oraz własnym chciałbym wyrazić ogromne uznanie, podziękowanie oraz podziw dla naszego wielkiego Narodu za sposób, w jaki zdaje egzamin w bardzo trudnym dla nas wszystkich czasie zarazy (ibid.).

(10) Głęboko wierzę, że nasz wielki Naród przetrwa straszny czas i wyjdzie z tego bolesnego doświadczenia mądrzejszy i silniejszy (ibid.).

Wśród przywołanych przykładów uwagę przykuwać może ponadto nacechowany emfazą obraz ojczyzny jako cierpiącej matki rozpoczynający orędzie (por. (8)). Siła perswazyjna takiej figury wynika z odwołania do budzącego emocje motywu stabat Mater Dolorosa. Wzmacnia ją jednocześnie na mocy argumentum ad reverentiam (argument odwołujący się do podziwu) osoba autora cytowanych słów - św. Jana Pawła II. Papież występuje tu w roli autorytetu niepodważalnego (podkreśla to 
określenie wielki rodak). Wykorzystanie szacunku odbiorców do papieskiego autorytetu służyć ma umocnieniu pozycji przemawiającego.

Niepewność wśród odbiorców wzbudzić ma również argumentacja ad metum (odwołująca się do strachu) używana zarówno przez marszałka Grodzkiego, jak i marszałek Witek; por.:

(11) Jednak dziś wszyscy zadajemy sobie to samo pytanie: czy pokonamy zagrożenie, z którym przyszło się nam zmierzyć? Jaka będzie przyszłość? Czy poradzimy sobie ze skutkami tego kryzysu? Czy nasz świat, nasze życie znowu będzie mogło być takie samo? Wielu z nas myśli o tym, co będzie z pracą, kiedy dzieci wrócą do szkoły, jak spędzimy Święta Wielkanocne. Stawiane są pytania o przyszłość Polski. Myślimy, co będzie z naszą gospodarką, ze stabilnością finansów publicznych. W tym morzu znaków zapytania pojawia się również pytanie, czy odbędą się wybory prezydenckie - sól naszej demokracji i instytucjonalnej stabilności państwa (Witek 2020).

(12) Ogromnym wysiłkiem Narodu, godzącego się na drastyczne ograniczenia w imię skutecznej walki z wirusem, staramy się jak najszybciej zwalczyć pandemię. Martwimy się o to, czy nasze dzieci, wnuki, rodzice i dziadkowie będą zdrowi i czy przeżyją, czy nie zostaniemy skazani na głodowe dochody i czy nie stracimy pracy. Lekarze, pielęgniarki, ratownicy, laboranci, farmaceuci martwią się, czy dostaną odpowiednie środki ochronne, drżą, czy za walkę o życie i zdrowie chorych nie przyjdzie im zapłacić najwyższej ceny. Bolesne poczucie niepewności jutra towarzyszy nam teraz każdego dnia. To są nasze codzienne troski i zmartwienia, a nie wybory, które, jak uczy doświadczenie innych krajów, przeprowadzone w trakcie pandemii przyczyniają się do eksplozji zachorowań (Grodzki 2020).

Rozbudowane opisy społecznych lęków mają mieć efekt nie tylko w postaci konsolidacji obywateli wokół instytucji państwowych. Ich celem jest także dyskredytacja przeciwników politycznych, których oskarża się o wszczynanie konfliktów i destabilizowanie państwa w obliczu sytuacji kryzysowej. Językowe wykładniki retoryki strachu odnaleźć można zarówno w serii zadawanych przez marszałek Witek pytań retorycznych (Czy pokonamy zagrożenie, z którym przyszło się nam zmierzyć?, Jaka będzie przyszłość?), jak i w używanych przez marszałka Grodzkiego czasownikach konotujących negatywne emocje (martwić się / drżeć) oraz frazeologizmach oddziałujących na wyobraźnię odbiorców (zapłacić najwyższa cenę / głodowe dochody / codzienne troski i zmartwienia).

Ważnym elementem każdego z analizowanych orędzi jest skierowany do odbiorców apel o odpowiedzialność i z rozsądek. Kompozycyjna dominanta apelu najwyraźniej zaznacza się w odezwach prezydenta. Wynika to z przyjętej przez niego strategii wizerunkowej, wedle której występuje on jako swego rodzaju pater fami- 
lias - ojciec narodu wyrażający troskę zarówno o obywateli, jak i o rządzących. Prezydent prośbę o mądre i zdyscyplinowane zachowanie kieruje do rodaków w obu swoich wystąpieniach; por.:

(13) Podejdźmy ze zrozumieniem do tych działań. Proszę uważnie śledzić wszystkie zalecenia wydawane przez służby i do nich się stosować. Apelując o zachowanie spokoju i zdrowego rozsądku, pamiętajmy równocześnie - nauczeni doświadczeniem innych krajów - że sprawa jest poważna. Nie wolno jej lekceważyć (Duda 2020a).

(14) [...] apeluję do wszystkich o jeszcze większą mobilizację, jeszcze większą dyscyplinę. Zostańmy w domach! Stosujmy się do wydawanych zaleceń. Nie ryzykujmy zdrowiem i życiem własnym oraz innych osób. Pamiętajmy o doświadczeniach innych państw: szybko rosnąca liczba zakażeń i zachorowań jest zawsze wynikiem lekkomyślności i lekceważenia podstawowych reguł bezpieczeństwa (Duda 2020b).

Siłę perswazyjnego oddziaływania mogą nieść także pojawiające się w orędziach akty podziękowań. Politycy, dziękując współobywatelom, odwołują się do poczucia pychy i narodowej dumy. Takie działanie z jednej strony służy pozyskaniu odbiorców, z drugiej zaś ma ich przekonać do sposobu postępowania, który mówca chwali. W charakterze wzoru przedstawiani są m.in.: lekarze, żołnierze czy naukowcy; por.:

(15) W tych trudnych dla nas wszystkich dniach z całego serca dziękuję służbom sanitarnym, medycznym i mundurowym. Dziękuję żołnierzom Wojska Polskiego oraz tym z Państwa, którzy zabezpieczają (sic!) dostęp do najpotrzebniejszych usług i towarów. Wykazują się Państwo szczególnym hartem ducha. Państwa oddanie i profesjonalizm wzbudzają w sercach Polaków spokój, zaufanie i autentyczny podziw. Inspirują też do udzielania pomocy potrzebującym (ibid.).

(16) W imieniu Senatu Rzeczypospolitej oraz własnym chciałbym wyrazić ogromne uznanie, podziękowanie oraz podziw dla naszego wielkiego narodu za sposób, w jaki zdaje egzamin w bardzo trudnym dla nas wszystkich czasie zarazy. Wielu z Państwa szyje maski i fartuchy, a nasi naukowcy intensywnie pracują nad skutecznymi terapiami i szczepionką (Grodzki 2020).

Dużą moc przekonywania ma również argumentacja odwołująca się do wyznawanych wartości. Taki rodzaj argumentowania jest jednak skuteczny tylko wtedy, gdy nadawca posługuje się nazwami wartości, które są ważne dla odbiorcy; por.:

Każdy z nas ma jakąś hierarchię wartości i przekonań. Niektóre z nich, nabyte w sposób bardziej świadomy, podlegają dyskusji i ewentualnej zmianie. Jednak każdy z nas 
ma również pewne głęboko uwewnętrznione wartości moralne niepodatne na argumentację. Są wartości, których podważenie oznaczałoby destrukcję osobowości. Jeżeli mogą one ulec zmianie, to tylko w wyniku długotrwałego powolnego procesu [...]. W trakcie polemiki takie wartości są jednak niepodważalne (Kisielewicz 2017: 54).

W orędziach przywoływane są zatem najczęściej pojęcia znajdujące się w katalogu słów sztandarowych (por. Pisarek 2000) i mieszczące się w aksjologicznym kanonie polskich wartości (por. Bartmiński 2014), takie jak: patriotyzm, ojczyzna, suwerenność, wolność, demokracja itp.

W analizowanych tekstach najczęściej przywoływaną wartością jest wspólnotowość. Politycy mówią o wspólnym działaniu, konieczności jednoczenia się i współpracy w trudnych chwilach, przykładach wzajemnego wspierania się, a także poczuciu narodowej jedności i solidarności. Podkreśla się konieczność odłożenia na bok doraźnych sporów politycznych oraz zwraca uwagę na to, że walka z koronawirusem nie ma barw politycznych; por.:

(17) Walka $\mathrm{z}$ koronawirusem nie ma barw politycznych. Jego zwalczanie jest naszym wspólnym zadaniem i obowiązkiem (Duda 2020a).

(18) Działając wspólnie, w poczuciu narodowej jedności i solidarności, jak dotąd zapobiegliśmy lawinowemu wzrostowi liczby zakażonych (Duda 202ob).

(19) Wierzę, że to się uda, i wierzę, że przed nami jeszcze wiele dobrych dni. Wszystko będzie dobrze. Musimy tylko wytrwać. Wspólnie to pokonamy! (Witek 2020)

(20) Wszystkie partie i ugrupowania muszą odłożyć na bok doraźne spory polityczne i razem uczynić wszystko, aby nie dopuścić do igrania z bezpieczeństwem rodaków w środku pandemii (Grodzki 2020).

Do odpowiedzialnego zachowania przekonać odbiorców ma też odwoływanie się do wartości, jaką jest bezpieczeństwo, zarówno zdrowotne, jak i finansowe; por.:

(21) Musimy ochronić nie tylko życie i zdrowie, ale też materialne podstawy bytu milionów polskich rodzin (Duda 2020b).

(22) Życie i zdrowie Polaków jest dla nas najwyższą wartością. Nic nie stoi ponad to. I dziś robimy wszystko, by te wartości ochronić. Są one w centrum naszej uwagi (Witek 2020).

(23) Organizacja wyborów w szczycie epidemii to narażanie życia i zdrowia Polek i Polaków (Grodzki 2020).

Wreszcie (co podkreślają zarówno marszałek sejmu, jak i marszałek senatu) wartością, o którą należy dbać, jest demokracja; por.: 
(24) Nie ma demokracji bez pełnej wyborczej podstawy. [...] Ciągłość utrzymania porządku instytucjonalnego państwa w takim kryzysie jak dziś powinna przyświecać nam wszystkim, niezależnie od barw politycznych czy poglądów (Witek 2020).

(25) Polonia protestuje, gdyż w wielu miejscach obawia się, że zostanie pozbawiona możliwości głosowania. Jak ktoś może twierdzić, że troska o zdrowie i życie rodaków oraz o demokratyczne i zgodne z konstytucją wybory jest złośliwością? (Grodzki 2020)

W tym kontekście politycy podkreślają, że na sercu leży im sprawna i zgodna z prawem organizacja wyborów, które marszałek Witek nazywa sola naszej demokracji, a marszałek Grodzki świętem demokracji.

$\mathrm{W}$ analizowanych przemówieniach zwraca uwagę podkreślanie, że przywoływane wartości znajdują się w stanie zagrożenia i konieczna jest ich ochrona. W tym celu $\mathrm{z}$ jednej strony apeluje się o postępowanie zgodne $\mathrm{z}$ zalecaniami rządzących. $\mathrm{Z}$ drugiej - zwraca się uwagę na to, że niebezpieczeństwo wiąże się nie tylko z pandemią, ale też z działaniami politycznych przeciwników, którym zależy na wszczęciu konfliktu politycznego w trakcie trudnego dla narodu momentu. Nawoływaniu do zgody narodowej towarzyszy więc kontynuacja retoryki dzielącej społeczeństwo na linii MY - ONI.

Ostatnim elementem analizowanych orędzi jest próba przekonania słuchaczy co do słuszności i skuteczności przyjętych strategii walki ze skutkami kryzysu. Prezydent w swoich przemówieniach stara się zaprezentować jako główny organizator działań antykryzysowych. Korzysta ze wskazywanej już wcześniej figury ojca naro$\mathrm{du}$, a także niezależnego i bezstronnego arbitra w politycznym sporze między rządem a opozycją. Wyraźnie podkreśla swoją rolę w podejmowanych przez państwo działaniach. Przejawia się to pod postacią wypowiedzi autoreferencyjnych wykorzystujących formy czasowników i zaimków w pierwszej osobie liczby pojedynczej; por.:

(26) Na moją prośbę odbyło się specjalne posiedzenie sejmu, na którym przyjęto ustawę mającą ułatwić walkę z zagrożeniem. Niezwłocznie ją podpisałem i już obowiązuje. Dzisiaj zwołałem posiedzenie Rady Bezpieczeństwa Narodowego, by rząd i przedstawiciele opozycji mogli ze mną wspólnie rozmawiać o sposobach zapewnienia Polakom bezpieczeństwa (Duda 2020a).

(27) Dzisiaj otrzymałem rządowy projekt specjalnej ustawy określanej jako „tarcza antykryzysowa”. [...] Z uwagi na rangę tego aktu prawnego zwołałem posiedzenie Rady Bezpieczeństwa Narodowego (Duda 2020b).

Inną strategią posługują się marszałkowie sejmu i senatu, którzy nie tylko przekonują o zasadności podejmowanych przez siebie działań, ale też czyniąc użytek z argumentacji ad vertiginem (do lekkomyślności), starają się przedstawić przeciwników 
politycznych jako niezdolnych do właściwej oceny sytuacji. Marszałek Witek korzysta w tym celu z figury apelu, który kieruje jednak nie do odbiorców, a do marszałka senatu. Zwraca się do niego z prośbą o poważne i odpowiedzialne procedowanie przyjętej przez sejm ustawy wprowadzającej zmiany w kodeksie wyborczym; por.:

(28) [...] aby udało się skutecznie wprowadzić te zmiany, czasu mamy mało i niezbędna jest płynna współpraca sejmu, senatu i prezydenta. Jako marszałek sejmu zapewniam o gotowości do szybkiego, sprawnego i zgodnego procedowania nad tym projektem. Chciałabym również zaapelować do marszałka senatu, aby izba wyższa również poważnie i odpowiedzialnie podeszła do tego zadania. Apeluję o sprawne procedowanie tej ustawy w senacie, bowiem od uchwalenia jej w sejmie pozostanie dosłownie kilka dni, aby prezydent mógł podpisać te zmiany i by mogły one działać (Witek 2020).

Konieczność wystosowania takiego apelu presuponuje, że rozwaga i odpowiedzialność nie należą do cech przypisywanych przez marszałek sejmu izbie wyższej i jej reprezentantom. Siłę retoryczną tego argumentu wzmacnia nadto nagła zmiana adresata wypowiedzi, co jest $\mathrm{w}$ tego rodzaju przemówieniach niespotykanym chwytem.

Przemówienie marszałka Grodzkiego również zawiera elementy polemiczne. Mówiący używa figury retorsio argumenti (odwrócenie argumentu) w celu przekonania odbiorców, że właśnie ze względu na wagę przygotowanej przez sejm ustawy konieczne jest procedowanie nad nią z zachowaniem zasad ostrożności. Jednocześnie działania podejmowane przez większość sejmową wprost nazywa bezrefleksyjnymi. Tę tezę wspiera przywołanie autorytetów Państwowej Komisji Wyborczej, Rzecznika Praw Obywatelskich i Sądu Najwyższego; por.:

(29) Niektórzy przedstawiciele rządu i niektóre media zarzucają senatowi, że złośliwie opóźnia rozpatrzenie ustawy o głosowaniu korespondencyjnym. Z całą mocą oświadczam, że to nieprawda. Przez sejm ta ważna ustawa przemknęła bezrefleksyjnie $\mathrm{w}$ ciągu 4 godzin, dlatego $\mathrm{w}$ senacie $\mathrm{w}$ ramach przysługujących nam konstytucyjnie 30 dni wykonujemy to, czego nie zrobił sejm: zapytaliśmy o opinię między innymi Państwową Komisję Wyborczą, Rzecznika Praw Obywatelskich, Sąd Najwyższy, epidemiologów czy pocztowców (Grodzki 2020).

Co więcej, orędzie marszałka Grodzkiego kończy się fragmentem piosenki zespołu Tilt; por.:

(30) Życzę Państwu, aby nasze marzenie o tym, że jeszcze będzie przepięknie, jeszcze będzie normalnie, ziściło się jak najprędzej (ibid.). 
Słowa „jeszcze będzie przepięknie, jeszcze będzie normalnie”, odnoszące się w piosence do wydarzeń w Polsce z 1989 r., są często wykorzystywane przez polityków sejmowej opozycji i jej sympatyków do wyrażenia niezadowolenia z obecnej sytuacji politycznej i nadziei na jej zmianę. Ponadto piosenka ta stała się hymnem kampanii wyborczej Platformy Obywatelskiej w wyborach parlamentarnych w $2007 \mathrm{r}$. Intertekstualne przywołanie tych słów w orędziu adresowanym do narodu sugeruje, że marszałek zwraca się przede wszystkim do konkretnej grupy - tych, którzy będą potrafili odczytać zakodowany komunikat. Warto zauważyć, że wraz ze zmianą adresata zmienia się również styl wypowiedzi - patos i emfazę, które charakteryzowały początek orędzia, zastępują potoczne skojarzenia.

$\mathrm{Na}$ uwagę zasługują także używane przez marszałka Grodzkiego ekspresywnie nacechowane sformułowania: igranie ze zdrowiem i życiem / niepohamowana żądza władzy / igranie $z$ bezpieczeństwem rodaków, por.:

(31) Jeśli wybory zwiększają ryzyko igrania ze zdrowiem i życiem, to naszym moralnym obowiązkiem i koniecznością jest przełożenie ich na czas, w którym pokonamy epidemię, przywrócimy normalne funkcjonowanie państwa i każdego z nas. Wtedy będzie pora na święto demokracji. Niepohamowana żądza władzy nie może triumfować nad walką o zdrowie i życie - nad przetrwaniem narodu. Wszystkie partie i ugrupowania muszą odłożyć na bok doraźne spory polityczne i razem uczynić wszystko, aby nie dopuścić do igrania $\mathrm{z}$ bezpieczeństwem rodaków w środku pandemii (ibid.).

Choć nadawca nie wskazuje jednoznacznie, komu przypisuje się tego rodzaju nierozsądne i egoistyczne działanie, to nietrudno odczytać ukrytą pod implikaturą próbę zdyskredytowania przeciwników politycznych.

Nie ulega wątpliwości, że wszystkie analizowane wystąpienia wpisują się w retorykę komunikacji kryzysowej. Ich głównym celem - w przeciwieństwie do orędzi okolicznościowych - nie jest integracja społeczeństwa wokół wspólnych wartości i narodowych dokonań, ale przekonanie rodaków o słuszności przyjętej przez państwo polityki w obliczu kryzysu. Wystąpienia najważniejszych państwowych urzędników mają wzbudzić zaufanie do instytucji państwa, a także uspokoić społeczne nastroje. Wszystkie analizowane teksty wykorzystują szereg strategii perswazyjnych. Ekspresywnie nacechowane określenia temporalne i argumentacja ad metum, a także odwołania do militarnej metaforyki służą zwróceniu uwagi obywateli na powagę zagrożenia związanego z pandemią. W obliczu niebezpiecznej sytuacji nadawcy odwołują się m.in. do takich pojęć, jak: wspólnotowość, bezpieczeństwo, demokracja. Należy jednak zauważyć, że te wartości traktowane są przez polityków w sposób instrumentalny. Ze wspólnoty wyznawanych wartości² ${ }^{2}$ wyklucza się przeciwników

2 Kwestii aksjologii w orędziach należałoby poświęcić rzecz jasna zdecydowanie więcej miejsca. Zdecydowałem się jednak nie rozbudowywać analizy problematyki związanej z tym zagadnieniem ze względu na ograniczenia objętościowe. 
politycznych, którym przypisywana jest lekkomyślność działania (argumentacja ad vertiginem), a nawet chęć wyzyskania zaistniałego kryzysu dla własnych korzyści kosztem zdrowia i życia obywateli. Element ten szczególnie dobrze widoczny jest w wypowiedziach marszałków sejmu i senatu. Nieco bardziej stonowane jest pod tym względem przemówienie prezydenta, który występuje w dwojakiej roli - głowy państwa, ale też i kandydata w zbliżających się wyborach. Zgodnie z przyjętą strategią wizerunkową próbuje on kreować się na ojca narodu, który dba o obywateli. Skupia się na wygłaszaniu rad, apeli i podziękowań, a także podkreślaniu swojej roli w przeciwdziałaniu skutkom pandemii. Interesującym zjawiskiem dającym się zauważyć $\mathrm{w}$ analizowanych tekstach jest płynne przełączanie przez nadawców wykorzystywanych kodów (np. przejście ze stylu patetycznego do potocznego w wypowiedzi marszałka Grodzkiego), a także docelowego odbiorcy (orędzia marszałka Grodzkiego i marszałek Witek). Na tej podstawie stwierdzić można, że orędzie to gatunek polimorficzny. Wśród jego atrybutów wymienić należy m.in.: szeroki kanał rozpowszechnienia (najczęściej telewizyjny), konwencjonalizację i rytualizację, a także związane z nimi patos i powagę (zarówno w warstwie leksykalnej, tekstowej, jak i wizualnej). Analizowane orędzia podporządkowane są jednak funkcji perswazyjnej. Zmianie, zależnie od retorycznych celów przemawiających, ulegać może zarówno stopień podniosłości, jak i wykorzystywany przez nadawców zasób środków argumentacyjnych. Wydaje się, że orędzia na czas kryzysu różnić będą się pod tym względem od swoich okolicznościowych odpowiedników, które charakteryzuje większy stopień skonwencjonalizowania i dominacja funkcji emotywnej.

\section{Źródła}

Duda A., 2020a, Orędzie Prezydenta, [on-line:] https://www.youtube.com/watch?v=RjdJ Fed46uM/. (dostęp: 8 V 2020).

Duda A., 202ob, Orędzie Prezydenta Andrzeja Dudy| 20 marca 2020, [on-line:] https://www. youtube.com/watch?v=T8oewLWESzE/ (dostęp: 8 V 2020).

Grodzki T., 2020, Orędzie Marszałka Senatu prof. Tomasza Grodzkiego, [on-line:] https:// www.youtube.com/watch?v=RBYwG2W-Px4/ (dostęp: 8 V 2020).

Konstytucja Rzeczypospolitej Polskiej z dnia 2 kwietnia 1997 r. (Dz.U. 1997, nr 78, poz. 483).

Rozporządzenie KRRiT z dnia 21 sierpnia 1996 r. w sprawie trybu postępowania w związku z prezentowaniem i wyjaśnianiem w publicznej radiofonii i telewizji polityki państwa przez naczelne organy państwowe (Dz.U. 1996, nr 109, poz. 526).

Ustawa z dnia 19 grudnia 1992 r. o radiofonii i telewizji (Dz.U 2020, poz. 805).

Wiтек E., 2020, Orędzie marszałek Sejmu Elżbiety Witek, [on-line:] https://www.youtube. com/watch?v=doqKQgXe2Lg// (dostęp: 8 V 2020). 


\section{Literatura}

Banaszak B., 2009, Konstytucja Rzeczypospolitej Polskiej. Komentarz, Warszawa.

BArtmiński J., 2014, Polskie wartości w europejskiej aksjosferze, Lublin.

Czachur W., 2016, Inscenizowanie bliskości w polskich i niemieckich orędziach noworocznych. Przyczynek do lingwistyki kulturowej i międzykulturowej, [w:] J. Górnikiewicz, B. Marczuk, I. Piechnik (red.), Études sur le texte dédiées à Halina Grzmil-Tylutki, Kraków, s. 73-96.

Kisielewicz A., 2017, Logika i argumentacja. Praktyczny kurs krytycznego myślenia, Warszawa.

Kuczma P., 2015, Orędzia prezydenta, „Zeszyty Naukowe DWSPiT. Studia z Nauk Społecznych" 8, s. 189-206.

NoIŃsKa M., 2017, Wartości w orędziach noworocznych polskich, rosyjskich i niemieckich przywódców w latach 2012-2015, „Przegląd Wschodnioeuropejski” VIII/2, s. 397-405.

Noińska M., 2018, Co roku to samo... Z historii orędzia noworocznego w Polsce, Niemczech $i$ Rosji, „Przegląd Wschodnioeuropejski” IX/2, s. 95-104.

Patocka-Sigıowy U., 2011, Orędzie prezydenckie jako gatunek wypowiedzi politycznej, [w:] A. Filipczak-Białkowska (red.), Dyskursy komunikacji medialnej, Łódź, s. 93-100.

Pisarek W., 200o, Polskie słowa sztandarowe i ich publiczność: lata dziewięćdziesiąte, „Zeszyty Prasoznawcze" XLIII, nr 3-4, s. 19-41.

TworzydŁo D., 2012, Komunikacja w kryzysie elementem budowy skutecznej marki, „Prace Instytutu Lotnictwa" nr 1 (222), s. 149-16o.

\section{Television Address to the Nation as a Tool of Crisis Communication Summary}

Since the coronavirus pandemic began, the institutions of the Polish state have been using various communication methods to minimise the potential impact of the crisis. Such methods include press conferences, social campaigns, and messages broadcast on TV and in the Internet. In addition, the most important people in the country (the President of the Republic of Poland, the Speaker of the Sejm and the Speaker of the Senate) have decided to use their right to speak to the nation in the form of TV addresses. The aim of this article is to analyse the rhetorical and argumentative layer of these speeches, and to describe the most important persuasive strategies used by the politicians to mitigate the negative effects of the crisis of the image of the country. 